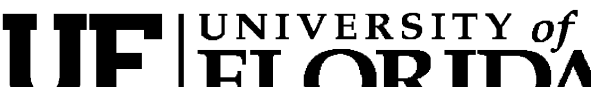 FLORIDA \\ IFAS Extension
}

\section{Understanding Sexual Minority Adolescents 1}

\section{Christine Regan and Kate Fogarty ${ }^{2}$ \\ Sexual orientation: What is it?}

Sexual orientation is a sensitive issue that affects all stages of life in many settings, including the family, school, and workplace. In its most simple form, sexual orientation is defined by the direction of one's emotional and physical attraction. Someone who has a heterosexual orientation is attracted to members of the opposite sex, while someone with a homosexual orientation is attracted to members of the same sex. When someone is attracted to both sexes, she or he is considered to have a bisexual orientation. Many believe sexual orientation is a continuum--that these three categories are limiting and incomplete (Kinsey, et al, 1948; 1953). However, they do serve as a basis for understanding sexual orientation at its most basic level. The purpose of this publication is to educate staff and volunteers working in community-based settings about sexual minority or lesbian, gay, bisexual, and transgendered (LGBT) adolescents and the challenges they face.

\section{Development of a homosexual orientation}

There are several explanations for how a person develops his or her sexual orientation, particularly homosexuality. The following theory, developed by researcher Vivienne Cass, proposes that a homosexual identity develops in stages. The stages are as follows:

1) Identity confusion. An individual may feel "different" than her/his peers. The individual struggles with having a homosexual identity and either reject or accept this label for her- or himself.

2) Identity comparison. A person considers the possibility that she or he may be homosexual and examines their own thinking about homosexuality and heterosexuality. As a result, they decide whether having a homosexual identity is positive (homosexuality as good) or negative (denying this identity). For those who feel it is negative, they will remain at this stage until that feeling begins to change.

3) Identity tolerance. The person has begun to accept her- or himself as a homosexual and therefore seeks to know other homosexuals, who either accept

1. This document is FYCS 9237, one of a series of the Department of Family, Youth and Community Sciences, Cooperative Extension Service, Institute of Food and Agricultural Sciences, University of Florida. Publication date: August 2006. Please visit the EDIS website at http://edis.ifas.ufl.edu

2. Christine Regan, Master of Science candidate, and Kate Fogarty, assistant professor, both of the Department of Family, Youth and Community Sciences, Cooperative Extension Service, Institute of Food and Agricultural Sciences, University of Florida, Gainesville, FL, 32611.

The Institute of Food and Agricultural Sciences (IFAS) is an Equal Opportunity Institution authorized to provide research, educational information and other services only to individuals and institutions that function with non-discrimination with respect to race, creed, color, religion, age, disability, sex, sexual orientation, marital status, national origin, political opinions or affiliations. U.S. Department of Agriculture, Cooperative Extension Service, University of Florida, IFAS, Florida A. \& M. University Cooperative Extension Program, and Boards of County Commissioners Cooperating. Larry Arrington, Dean 
or reject this person's connection to the group of other homosexuals.

4) Identity acceptance. The person fully accepts her/his own homosexual identity and her/his reference group. This person may find comfort in her/his identity, yet feel pressure to fit into majority culture. Due to perceived pressures from family members and peers as well as those within the work and school environments, they may continue to pretend to be heterosexual. This is referred to as "passing."

5) Identity pride. A person at this stage will share her/his pride in a homosexual identity with others and start to express her/his identity as a way to combat homophobia.

6) Identity synthesis. A person will fully include her/his homosexual identity into their lifestyle. At this stage a person continues to build an increasingly integrated homosexual identity (Cass, 1979; 1984).

Cass's stage-based explanation of how individuals develop a homosexual orientation is useful for several reasons. These stages: (1) show that developing a homosexual orientation is a process, not something that just happens overnight; (2) support the development of a homosexual identity as a positive developmental pathway, rather than an abnormality; and (3) demonstrate what adolescents may be experiencing at each stage, so adults and/or peers can better understand them. Furthermore, it is not assumed that the development of a homosexual identity only happens by a persons own choice. Instead, people who progress down this pathway are influenced by both individual dispositions (biological tendencies) and their environments (peers, family, community members) (Murphy, 2005). Decisions whether to accept this identity are made at each stage--ones that are not always easy to make--based on disapproval by important people in their lives.

\section{Additional challenges for LGBT Adolescents}

All adolescents experience the same physical, cognitive, psychological, and social processes of development. While adolescence is a difficult time for all individuals, sexual minority youth often lack the support structures that most heterosexual teens are able to utilize (Cato \& Canetto, 2003; Gonsiorek, 1998). Furthermore, since one of the major and most challenging psychological tasks of adolescence is forming a sexual identity, LGBT adolescents face a myriad of challenges and struggles that heterosexual adolescents do not. For example, within their own communities, LGBT adolescents:

- experience more physical and verbal abuse (Cato \& Canetto, 2003);

- experience more depression and low self-esteem (DAugelli, et al, 2002);

- experience more victimization (Mufioz-Plaza, et al, 2002);

- are more prone to attempt suicide than their heterosexual peers (McDaniel, 2001);

- can hear up to twenty-five anti-gay remarks a day (Anthanases \& Larrabee, 2003) (GLSEN, 2003);

- report missing at least one entire day of high school in the past month because they felt unsafe (Anthanases \& Larrabee, 2003) (GLSEN, 2003).

The majority of LGBT students in school settings also claim that a teacher or professional was aware of these remarks or behaviors and did nothing to correct the situation. If one considers that homosexual identity develops in stages, and that not all adolescents "come out" (tell others about his/her orientation) simultaneously, homophobic comments may also have damaging effects on youth who may identify as gay, lesbian, or bisexual, but are still "closeted" (not open about their sexuality). It is likely that homophobic remarks are hurting more sexual minority adolescents than their peers or teachers realize.

\section{Number of people affected}

Although the majority of youth are heterosexual, there are more than 2 million school-aged gay, lesbian, bisexual, and transgendered youth (NHMA, 2005). Two million may seem insignificant, however, this number does not include youth who are 
questioning their sexuality, unsure about it, or not yet open about their sexual orientation. The challenges faced by this group of adolescents can have lasting, damaging results if proper support is not available. Furthermore, an estimated 2-8 million parents in the placecountry-regionUnited States are gay, lesbian, or bisexual (Kaiser Family Foundation, 2001). Although their children may themselves be heterosexual, research has shown that adolescents with gay or lesbian parents are also ridiculed or treated poorly (DAugelli \& Hershberger, 1993). Both adolescents and adults inevitably turn to at least one person for support through hard times, totaling over at least 16 million Americans negatively affected by these challenges.

\section{Abuse occurs in many settings}

This abuse occurs not only in schools and within families, but is also reflected in a variety of community settings. Community organizations are not always supportive or inclusive of gay and lesbian issues (Keefer \& Reene, 2002). In local communities across the country, hate crimes are brought upon gay or lesbian individuals on a daily basis. In 2003, there were 1,479 hate crimes committed with sexual orientation as the motivation for the crime (FBI, 2003). The widely publicized murder of Matthew Sheppard, a teenager in CityplaceLaramie, StateWyoming, was committed by two adult males merely because of Matthew's sexual orientation. On a smaller scale, damage can also be done when adult leaders say things such as, "There's something funny about that kid," or "As a parent, I don't want that kid sleeping in my son's cabin" to other adults they work with in a community setting. This creates an atmosphere of intolerance and inhibits positive youth development.

\section{Conclusion}

Understanding the "coming out" process is important in helping sexual minority adolescents foster a positive sense of well-being, feel accepted by others, and succeed both academically and personally. Understanding the challenges faced by LGBT adolescents and the stages of homosexual identity development has applications in many areas affecting youth including: community-based youth organizations (such as 4-H, schools, county extension programs, mental health counseling, adolescent medicine, and diversity-based programs). Adults who work with youth are the key for advocating a safer, more equitable environment for sexual minority adolescents.

\section{Resources for adults who work with youth (also see national organizations below)}

- The American Psychological Association's Healthy Lesbian, Gay, and Bisexual Students Project works with schools to help prevent risky behaviors and improve health outcomes for lesbian, gay, and bisexual youth. http://www.apa.org/ed/hlgb/

- The Gay and Straight Educators Network combats harassment and discrimination of gay students and school personnel. http://www.glsen.org/cgi-bin/iowa/educator/ educator/index.html

- The NEA's "Strengthening the Learning Environment: An Education Employee's Guide to Gay and Lesbian Issues. http://www.nea.org/nr/02taskforce.html

- Parents and Friends of Lesbians and Gays. http://www.pflag.org/index.php?id=83\# 1

\section{Resources for youth}

- Book resources. http://www.bidstrup.com/parbiblio.htm

- Campus Pride. http://www.campuspride.net

- Coming out Stories. http://www.rslevinson.com/gaylesissues/ comingoutstories/blcoming_youth.htm

- Equality Ride. http://www.equalityride.com

- Gay and Lesbian National Hotline. http://www.glnh.org/index.html

- Gay Health. http://www.gayhealth.com/templates/0/ index.html 
- Gay Youth Corner. http://www.thegyc.com

- Outproud. http://www.outproud.org

- Queer America. http://www.queeramerica.com/

- Young Gay America.

http://www.younggayamerica.com/index 1.shtml

- Youth.org. http://www.youth.org/

- Youthline. http://www.youthline.ca/

- Youth Resource. http://www.youthresource.com

\section{Religious organizations that support sexual minority adolescents}

- Affirmation: (Latter Day Saints). http://www.affirmation.org/

- Affirmation: (United Methodists). http://www.umaffirm.org/

- Association of Welcoming and Affirming

Baptists. http://www.wabaptists.org/

- Christian Alliance for Progress. http://www.christianalliance.org/

- Friends for LGBTQ Concerns (Quakers). http://www.quaker.org/flgbtqc/

- Integrity (Episcopalian). http://www.integrityusa.org/

- Lutherans Concerned. http://www.lcna.org/

- Metropolitan Community Church. http://mccchurch.org/

- Presbyterian for LGTBQ Concerns. http://www.mlp.org/

- Seventh-Day Adventist Kinship. http://www.sdakinship.org/

- Soul Force (All faiths). http://www.soulforce.org/

- Truth Sets Free (All faiths). http://www.truthsetsfree.net/
- Unity Fellowship of Church of Christ. http://www.ufc-usa.org/

- World Congress of LGBT Jews. http://glbtjews.org/

\section{National organizations that support sexual minority adolescents}

- American Academy of Child and Adolescent Psychiatry. http://www.aacap.org

- American Psychological Association. http://www.apa.org/pi/lgbc/policy/pshome.html

- American School Counselor Association. http://www.schoolcounselor.org

- Association of Gay and Lesbian Psychiatrists. http://www.aglp.org

- Human Rights Campaign. http://www.hrc.org

- Human Rights Watch. http://www.hrw.org

- National Association of School Psychologists. http:// www.nasponline.org

- National Education Association. http://www.nea.org

- National Gay and Lesbian Task Force. http://www.thetaskforce.org/

- National Mental Health Association. http://www.nmha.org/pbedu/backtoschool/ bullyingGayYouth.cfm

\section{References}

Anthanases, Steven Z. \& Larrabee, Timothy G. (2003). Toward a consistent stance in teaching for equity: Learning to advocate for Lesbian- and Gay-identified youth. Teaching and Teacher Education, 19(2), 237-261.

Benson, Peter L. (1997). All Kids Are Our Kids. San Francisco: Jossey-Bass.

Cass, V. C. (1979). Homosexual identity formation: A theoretical model. Journal of Homosexuality, 4, 219-235. 
Cass, V.C. (1984). Homosexual Identity: A

Concept in Need of Definition.Journal of

Homosexuality, 9(2-3), 105-126.

Cato, J. \& Canetto, S.S. (2003). Young adults reactions to gay and lesbian peers who became suicidal following "coming out" to their parents. Suicide and Life-Threatening Behavior, 33(2), 201-210.

DAugelli, A. \& Hershberger, S. (1993). Lesbian, gay, and bisexual youth in community settings: Personal challenges and mental health problems. American Journal of Community Psychology, 21, 421-448.

DAugelli, A., Hershberger, S. \& Pilkington, N. (2002). Incidence and mental health impact of sexual orientation victimization of lesbian, gay and bisexual youths in high school. School Psychology Quarterly, 17(2), 148-167.

Federal Bureau of Investigation (FBI). (2003). Hate Crime Statistics: 2005. Retrieved on August 11, 2005 from http://www.fbi.gov/ucr/03hc.pdf.

Gonsiorek, J. (1998). Mental health issues of gay and lesbian adolescents. Journal of Adolescent Health Care, 9, 114-122.

Gay, Lesbian, Straight Education Network. (2003). The 2003 National Climate Survey. Retrieved on February 11, 2005 from http://www.glsen.org/binary-data/GLSEN_ ATTACHMENTS/file/300-3.PDF.

Kaiser Family Foundation. (2001). New surveys on experiences of lesbians, gays and bisexuals and the public's views related to sexual orientation. Retrieved on August 10, 2005 from http://www.kff.org/kaiserpolls/3193-index.cfm.

Keefer, B. P. \& Reene, K. (2002). Female adolescence: Difficult for heterosexual girls, hazardous for lesbians. Annual of Psychoanalysis, 30, 245-253.

Kinsey, A., Pomeroy, W., and Martin, C. (1948). Sexual behavior in the human male. Philadelphia: W.B. Saunders.
Kinsey, A., Pomeroy, W., Martin, C., and Gebhard, P. (1953). Sexual behavior in the human female. Philadelphia: W.B. Saunders.

McDaniel, J.S., Purcell, D. \& DAugelli, A.R. (2001). The relationship between sexual orientation and risk for suicide: Research findings and future directions for research and prevention. Suicide and Life-Threatening Behavior, 31, 84-105.

Mufioz-Plaza, C., Quinn, S.C., Rounds, K.A. (2002). Lesbian, gay, bisexual and transgender students: Perceived social support in the high school environment. The High School Journal, Apr/May 2002, 52-63.

Murphy, Timothy, F. (2005). The search for the gay gene. British Medical Journal, 330, (7498), 1033-1036.

National Mental Health Association (NMHA). (2005). What does gay mean? Retrieved on July 3, 2005 from http://www.nmha.org/whatdoesgaymean/ whatDoesGayMean.pdf. 